\title{
Evaluation of the ability of emergency medicine residents in teaching and supervising emergency medicine interns
}

\author{
Morteza Talebi Doluee ${ }^{1}$, Behrang Rezvani kakhki ${ }^{1}$, Maryam Salehi², Mahdi Talebi ${ }^{3}$, Maryam Emadzadeh ${ }^{4}$, \\ Maliheh Ziaee ${ }^{5}$
}

${ }^{1}$ Assistant Professor of Emergency Medicine, Department of Emergency Medicine, Faculty of Medicine, Mashhad University of Medical Sciences, Mashhad, Iran

${ }^{2}$ Associate Professor of Community Medicine, Research Center for Patient Safety, Mashhad University of Medical Science, Mashhad, Iran and Clinical Research Unit, Mashhad University of Medical Sciences, Mashhad, Iran

${ }^{3}$ Assistant Professor of Psychiatry, Department of family medicine, Faculty of Medicine, Mashhad University of Medical Sciences, Mashhad, Iran

${ }^{4}$ Assistant Professor of Community Medicine, Clinical Research Unit, Mashhad University of Medical Sciences, Mashhad, Iran

${ }^{5} \mathrm{MD}$, Specialist in Community Medicine, Psychiatry and Behavioral Sciences Research Center, Mashhad University of Medical Sciences, Mashhad, Iran

\section{Type of article: Original}

\begin{abstract}
Background: Approximately $25 \%$ of the residents' time in each shift is allocated to educating lower-level assistants and interns. Assistants have played a major role in interns' education.

Aim: To assess the teaching abilities of emergency medicine assistants in the training and monitoring of medical interns and undergraduate students.

Methods: This cross-sectional study was performed in 2015 at the emergency center of Imam Reza hospital in Mashhad University of Medical Sciences. We employed a researcher-made questionnaire to search the capability of emergency medicine residents to assess the teaching capabilities of emergency medicine residents to interns. This questionnaire was completed by 106 interns. The Validity of the questionnaire was confirmed by three specialist experts and reliability of the questionnaire was confirmed by Cronbach's alpha (0.94). This questionnaire consists of 24 questions in six areas. The analysis was performed by descriptive statistics using SPSS 16.

Result: The study showed that the least favorable score was related to "residents get feedback on each shift" and the highest score was given to "a friendly relationship with the Interns and residents".

Conclusion: Considering the key role of residents in the education and training of future healthcare specialists, training interventions and allocating sufficient time to the proper education of different members of healthcare teams and medical students could largely contribute to the development of clinical training systems.

Keywords: Emergency medicine, Medical education, Clinical education
\end{abstract}

\section{Introduction}

In a clinical setting, training and education are inherently based on the level of medical knowledge and acquiring clinical skills (1). In addition to care services, residents are required to provide training and education in every clinical department. As such, medical residents are faced with the challenge of establishing balance in their twofold role $(1,2)$. According to the literature, more than $40 \%$ of resident training is performed by the fellowship, and interns receive $25 \%$ of their training from residents (3). In a study by Sanchez, the majority of residents believed that their role as a trainer was important or the most important aspect of their profession. From their perspective, $45.5 \%$

\section{Corresponding author:}

Dr Maliheh Ziaee, Psychiatry and Behavioral Sciences Research Center, Mashhad University of Medical Sciences, Mashhad, Iran. Tel: +98.9155083897, Fax: +98.XXX, Email: ziaeem1@mums.ac.ir and malihehziaee@gmail.com Received: August 26, 2016, Accepted: April 14, 2017, Published: June 2017 iThenticate screening: February 14, 2017, English editing: May 30, 2017, Quality control: June 10, 2017 (C) 2017 The Authors. This is an open access article under the terms of the Creative Commons Attribution-NonCommercialNoDerivs License, which permits use and distribution in any medium, provided the original work is properly cited, the use is non-commercial and no modifications or adaptations are made. 
of their training was provided by other residents, and $90 \%$ stated that they had to practice and receive education in order to promote their training skills (4). Since most resident training programs are focused on acquiring and promoting clinical skills, many residents lack adequate training and communication skills in the clinical environment (1). Despite the perceived importance of this essential role for residents, they may not receive adequate formal training in teaching skills (5). Learning basic teaching skills should be part of the educational curriculum for medical residents (6). Moreover, previous studies have suggested that educational level is enhanced in the universities where medical assistants effectively contribute to the training of interns (6). In order to achieve medical teaching skills, the Society for Academic Emergency Medicine (SAEM), outlines six preliminary modules of a resident teacher-training program for emergency medicine residents. These modules are general principles of clinical teaching, bedside teaching, giving effective feedback, teaching procedures, teaching with high-fidelity patient simulation, teaching effective discussion, leading and lecturing (7). Undoubtedly, emergency sections are the essential element of each healthcare organization. Currently, most emergency departments are managed by general physicians due to the lack of emergency specialists. As future physicians, interns require comprehensive training on emergency medical services. Considering the integral association of interns with medical assistants, assistants play a pivotal role in education and training during internship $(3,8)$. This study aimed to assess the teaching abilities of emergency medicine assistants in the training and monitoring of medical interns and undergraduate students.

\section{Material and Methods}

This cross-sectional study was conducted at Mashhad University of Medical Sciences, Mashhad, Iran in 2015. This study was performed in the Edalatian emergency center in Imam Reza hospital which is the major emergency center in northeastern Iran. To assess the teaching capabilities of emergency medicine residents to interns, special questionnaires were completed. The questionnaire was developed based on the article of "Resident-as-teacher: a suggested curriculum for emergency medicine" classified in six main areas (7), guidelines of the "Resident Teacher Handbook" (9), and "Residents-as-teachers curricula: how to initiate, evaluate and sustain" (10). The questionnaire consisted of 24 items to evaluate six areas, including basic principles of medical education, clinical education, obtaining feedback, learning clinical skills, effective presentations, and education and training through simulated patients. Original questions were translated into Persian then back-translated to English by a fluent individual. To ensure the accuracy of translated items, the questionnaire was subsequently presented to three specialists to approve face and content validity. In addition, reliability of the questionnaire was confirmed after completion by 20 respondents. The reliability of the questionnaire was confirmed by the Cronbach's alpha of 0.94 . This questionnaire was filled out by 106 interns for evaluating the performance of the assistants of emergency medicine. Sampling method was convenience method and total of interns after one month of emergency medicine internship. The interns were asked to complete the questionnaire in order to express their opinion regarding the training performance of second-year emergency medicine residents. These residents were assigned in this time period, to lead these casebased teaching sessions with medical students as part of our study. In this study, we selected second-year emergency medicine residents for two reasons. First, considering the nature of emergency medicine, second-year residents have overlapping clinical shifts with first-year residents. Furthermore, second-year residents tend to have more free time to interact with medical interns and students. Basically, first-year emergency medicine residents need to follow the assigned tasks, and therefore, may not have the time to perform as teaching assistants. These residents mostly seek to resolve their own clinical issues and educational work. Items of the questionnaire were scored based on a fivepoint Likert scale (Strongly disagree, Disagree, Not sure, Agree, Strongly agree). For more tangible results, response to each of the questionnaire items were integrated and reported in three categories: disagree, I am not sure and agree. To evaluate and compare the results of each area, we calculated an average score for each reply, and scores above three were considered favorable. The analysis was performed by descriptive tests in SPSS, 16. Study protocol was approved by the Ethics Committee of Mashhad University of Medical Sciences, Iran. (Number: 910729).

\section{Results}

Our study showed that the least favorable score was related to "residents get feedback on each shift" and the highest score was given to "a friendly relationship with the interns and residents". Also in the current study, residents achieved a high score in the area of providing care services for patients (e.g., solving clinical problems and care provision, responsibility in providing the allocated services). According to the findings of the present study, 56.5\% of medical students believed that inadequate time is allocated to the training of students by residents. The results are shown in Table 1. 
Table1. Evaluating the performance of the assistants in emergency medicine

\begin{tabular}{|c|c|c|c|c|c|c|}
\hline \multirow[t]{2}{*}{ Domain } & \multirow[t]{2}{*}{ Items of questionnaire } & \multicolumn{5}{|c|}{ Answers; n (\%) } \\
\hline & & $\begin{array}{l}\text { Strongly } \\
\text { agree }\end{array}$ & Agree & $\begin{array}{l}\text { Not } \\
\text { sure }\end{array}$ & Disagree & $\begin{array}{l}\text { Strongly } \\
\text { disagree }\end{array}$ \\
\hline \multirow[t]{4}{*}{$\begin{array}{l}\text { The basics of medical } \\
\text { education }\end{array}$} & Appropriate occasion for training. & $9(8.5)$ & $41(38.7)$ & $\begin{array}{l}24 \\
(22.6)\end{array}$ & $\begin{array}{l}22 \\
(20.8)\end{array}$ & $8(7.5)$ \\
\hline & Sufficient time period for training. & $7(6.6)$ & $17(16)$ & $\begin{array}{l}21 \\
(19.8)\end{array}$ & $\begin{array}{l}41 \\
(38.7)\end{array}$ & $9(17.9)$ \\
\hline & $\begin{array}{l}\text { Giving right to participate in group } \\
\text { discussions during clinical rounds }\end{array}$ & $12(11.3)$ & $37(34.9)$ & $\begin{array}{l}26 \\
(24.5)\end{array}$ & $\begin{array}{l}21 \\
(19.8)\end{array}$ & $9(8.5)$ \\
\hline & $\begin{array}{l}\text { Necessary capabilities to act as the } \\
\text { teacher. }\end{array}$ & $5(4.7)$ & $27(25.5)$ & $\begin{array}{l}35 \\
(33)\end{array}$ & $\begin{array}{l}23 \\
(21.7)\end{array}$ & $14(13.2)$ \\
\hline Clinical education & Relevance to your educational needs. & $8(7.5)$ & $50(47.2)$ & $\begin{array}{l}17 \\
(16)\end{array}$ & $\begin{array}{l}22 \\
(20.8)\end{array}$ & $8(7.5)$ \\
\hline \multirow[t]{9}{*}{$\begin{array}{l}\text { Giving effective } \\
\text { feedback }\end{array}$} & $\begin{array}{l}\text { Giving feedback in every clinical } \\
\text { shift }\end{array}$ & $15(14.2)$ & 0 & $\begin{array}{l}47 \\
(44.3)\end{array}$ & $\begin{array}{l}32 \\
(30.2)\end{array}$ & $12(11.3)$ \\
\hline & Giving negative feedback typically & $24(22.6)$ & $46(43.4)$ & \begin{tabular}{|l|}
21 \\
$(19.8)$
\end{tabular} & $6(5.7)$ & $6(5.7)$ \\
\hline & $\begin{array}{l}\text { The feedbacks mostly have punitive } \\
\text { function. }\end{array}$ & $28(26.4)$ & $47(44.3)$ & \begin{tabular}{|l}
15 \\
$(14.2)$
\end{tabular} & $9(8.5)$ & $5(4.7)$ \\
\hline & $\begin{array}{l}\text { The manner of assistants' behavior } \\
\text { towards enthusiasm for training. }\end{array}$ & $10(9.4)$ & $49(46.2)$ & \begin{tabular}{|l|l|}
26 \\
$(24.5)$
\end{tabular} & $\begin{array}{l}13 \\
(12.3) \\
\end{array}$ & $7(6.6)$ \\
\hline & $\begin{array}{l}\text { Taking enough time for answering } \\
\text { questions }\end{array}$ & $9(8.5)$ & $47(44.3)$ & $\begin{array}{l}29 \\
(27.4)\end{array}$ & $18(17)$ & $2(1.9)$ \\
\hline & $\begin{array}{l}\text { Monitoring the manner of taking } \\
\text { biography and medical examinations. }\end{array}$ & $9(8.5)$ & $53(50)$ & $\begin{array}{l}22 \\
(20.8)\end{array}$ & $\begin{array}{l}15 \\
(14.2)\end{array}$ & $7(6.6)$ \\
\hline & $\begin{array}{l}\text { Asking about the patients' } \\
\text { differential diagnosis. }\end{array}$ & $6(5.7)$ & $30(28.3)$ & $\begin{array}{l}24 \\
(22.6)\end{array}$ & $\begin{array}{l}34 \\
(32.1)\end{array}$ & $10(9.4)$ \\
\hline & $\begin{array}{l}\text { Asking of opinion about the manner } \\
\text { of patients' clinical treatment. }\end{array}$ & $5(4.7)$ & $40(37.7)$ & $\begin{array}{l}22 \\
(20.8)\end{array}$ & $\begin{array}{l}25 \\
(23.6)\end{array}$ & $12(11.3)$ \\
\hline & $\begin{array}{l}\text { Stating the reason of accuracy or } \\
\text { inaccuracy of answers }\end{array}$ & $8(7.5)$ & $35(33)$ & $\begin{array}{l}37 \\
(34.9) \\
\end{array}$ & $17(16)$ & $7(6.6)$ \\
\hline \multirow[t]{2}{*}{$\begin{array}{l}\text { Training the clinical } \\
\text { skills }\end{array}$} & $\begin{array}{l}\text { Explaining the relevant indications } \\
\text { and contraindications before doing } \\
\text { the clinical procedures }\end{array}$ & $5(4.7)$ & $34(32.1)$ & \begin{tabular}{|l|l}
29 \\
$(27.4)$
\end{tabular} & $\begin{array}{l}26 \\
(24.5)\end{array}$ & $12(11.3)$ \\
\hline & $\begin{array}{l}\text { Explaining the way of doing the } \\
\text { procedure and its stages before doing } \\
\text { the procedure }\end{array}$ & $11(10.4)$ & $53(50)$ & $\begin{array}{l}23 \\
(21.7)\end{array}$ & $\begin{array}{l}14 \\
(13.2)\end{array}$ & $5(4.7)$ \\
\hline \multirow{5}{*}{$\begin{array}{l}\text { Training through } \\
\text { using simulated } \\
\text { patients }\end{array}$} & $\begin{array}{l}\text { Having a proper behavior towards } \\
\text { the patients }\end{array}$ & $14(13.2)$ & $53(50)$ & $\begin{array}{l}24 \\
(22.6)\end{array}$ & $7(6.6)$ & $5(4.7)$ \\
\hline & $\begin{array}{l}\text { Taking the responsibility of their } \\
\text { actions. }\end{array}$ & $17(16)$ & $57(53)$ & $\begin{array}{l}18 \\
(17)\end{array}$ & $9(8.5)$ & $4(3.8)$ \\
\hline & $\begin{array}{l}\text { Providing appropriate services to } \\
\text { patients. }\end{array}$ & $12(11.3)$ & $62(58.58)$ & \begin{tabular}{|l|l|}
18 \\
$(17)$
\end{tabular} & $10(9.4)$ & $3(2.8)$ \\
\hline & $\begin{array}{l}\text { Ability to synthesize the patients' } \\
\text { clinical problems. }\end{array}$ & $10(4.9)$ & $45(42.5)$ & $\begin{array}{l}33 \\
(31.1)\end{array}$ & $\begin{array}{l}12 \\
(11.3)\end{array}$ & $2(1.9)$ \\
\hline & $\begin{array}{l}\text { Asking for relevant tests, based on } \\
\text { the patients' problems. }\end{array}$ & $15(14.2)$ & $50(47.2)$ & $\begin{array}{l}24 \\
(22.6)\end{array}$ & $\begin{array}{l}11 \\
(10.4)\end{array}$ & $5(4.7)$ \\
\hline \multirow{3}{*}{$\begin{array}{l}\text { Teaching effective } \\
\text { speech and guiding } \\
\text { the discussion }\end{array}$} & Listening to your words attentively. & $11(10.4)$ & $62(58.5)$ & $\begin{array}{l}20 \\
(18.9)\end{array}$ & $7(6.6)$ & $3(2.8)$ \\
\hline & $\begin{array}{l}\text { Are content with teaching you and } \\
\text { show inclination to do it? }\end{array}$ & $8(7.5)$ & $55(51.9)$ & $\begin{array}{l}27 \\
(25.5) \\
\end{array}$ & $\begin{array}{l}13 \\
(12.3)\end{array}$ & $2(1.9)$ \\
\hline & $\begin{array}{l}\text { The friendly relationship between the } \\
\text { emergency medicine and you. }\end{array}$ & $29(27.4)$ & $50(47.2)$ & $\begin{array}{l}12 \\
(11.3)\end{array}$ & $7(6.6)$ & $8(7.5)$ \\
\hline
\end{tabular}




\section{Discussion}

In the present study, those residents were assessed and discussed by interns in six main areas. The highest score in the questionnaire belonged to the area of the friendly relationship between residents and interns, while the lowest score was observed in the category of obtaining feedback from interns by residents in every working shift. A study was conducted in Spain, and assessed the perception of 104 medical students about residents' teaching activity. In this study, these results were obtained: $69.9 \%$ of students consider that as much as $50 \%$ of their knowledge came from rounds with residents. Students believe that resident teaching lacks enough academicals' acknowledgment $(94.2 \%)$; they estimate necessary to acquire teaching skills during residency $(82.7 \%)$, and they would like to provide tutoring other medical students $(88,5 \%)$. Students have a positive view of residents and rated residents better than physicians on relational and motivational abilities (11). Neher et al. believed that in order to increase the teaching skills of medical assistants, they have to acquire the general principles of teaching and learn how to encourage students to learn new tips, assess the level of student knowledge and learning, adequately monitor and correct the mistakes of students, and reinforce the performance of students (12). Low score of obtaining feedback could be attributed to factors such as boredom, inadequate free time of residents due to multiple tasks, and lack of training skills. In a similar study, the highest scores of the questionnaire were reported in the areas of respecting students as individuals and answering the questions of students orally. On the other hand, the lowest score was observed in the area of facilitating the performance of interns through the use of pictorial training materials (8). Residents spend an estimated $20 \%$ of their clinical time supervising, evaluating and teaching students (13). In many institutions, medical students spend more time with residents than the faculty during their clinical rotations (5). Medical students spend significant amounts of time learning from residents and they are well-positioned to provide rapid and timely feedback to residents. They are reliable, and important judgment of them may facilitate residents' development as proficient teachers (14). In the current study, residents achieved a high score in the area of providing care services for patients (e.g., solving clinical problems and care provision, responsibility in providing the allocated services). In general, the majority of physicians do not receive training on teaching skills during the internship, while most resident training programs are based on the clinical abilities of physicians. Previous studies have proposed various theories regarding communication skills and promotion of training skills through acquiring residential clinical skills (1). According to the findings of the present study, $56.5 \%$ of medical students believed that inadequate time is allocated to the training of students by residents. This could be due to the fact that residents are mainly engaged in their assigned clinical tasks and do not have sufficient time for the training and education of interns. One other explanation for why residents were unable to assign more time to teach may be the increased involvement in other mandated training experiences (e.g., scholarly activity and quality improvement). The impact of duty hour restrictions and other responsibilities requirements should also be considered (15). Residents believe they are well adapted to teach their juniors, but report that their teaching role is not adequately emphasized or valued by their institution. Students may value resident teaching higher than faculty teaching. They view residents as more approachable, which enables them to admit ignorance and mistakes and more readily accept beneficial feedback (5). One of the limitations of the current study was the small sample size, and the results would be more accurate if similar studies were performed on larger sample sizes. In addition, the cross-sectional study design could be considered as another limitation of our study. Therefore, it is recommended that interventional studies should be conducted in this regard using various training methods to examine the results before and after the intervention. Moreover, educational interventions could be assessed in terms of their efficacy in the training of medical students and other residents.

\section{Conclusions}

According to the results of this study, residential curricula in the field of medicine do not meet the training needs of interns and undergraduate students regarding the enhancement of clinical training skills. Considering the key role of residents in the education and training of future healthcare specialists, training interventions and allocating sufficient time to the proper education of different members of healthcare teams and medical students could largely contribute to the development of clinical training systems.

\section{Acknowledgments:}

We thank all students who participated in completing the questionnaire.

\section{Conflict of Interest:}

There is no conflict of interest to be declared. 


\section{Authors' contributions:}

All authors contributed to this project and article equally. All authors read and approved the final manuscript.

\section{References:}

1) Cullimore AJ, Dalrymple JL, Dugoff L, Hueppchen NA, Casey PM, Chuang AW, et al. The obstetrics and gynaecology resident as teacher. J Obstet Gynaecol Can. 2010; 32(12): 1176-85. PMID: 21176331.

2) Hafler JP. Residents as teachers: a process for training and development. J Nutr. 2003; 133(2): 544S-6S. PMID: 12566499.

3) Hill AG, Yu TC, Barrow M, Hattie J. A systematic review of resident - as - teacher programmes. Med Educ. 2009; 43(12): 1129-40. doi: 10.1111/j.1365-2923.2009.03523.x. PMID: 19930503.

4) Sánchez-Mendiola M, Graue-Wiechers EL, Ruiz-Pérez LC, García-Durán R, Durante-Montiel I. The resident-as-teacher educational challenge: a needs assessment survey at the National Autonomous University of Mexico Faculty of Medicine. BMC Med Educ. 2010; 10(1): 17. doi: 10.1186/1472-6920-1017. PMID: 20156365, PMCID: PMC2830225.

5) Ramani S, Mann K, Taylor D, Thampy H. Residents as teachers: Near peer learning in clinical work settings: AMEE Guide No. 106. Med Teach. 2016; 38(7): 642-55. doi: 10.3109/0142159x.2016.1147540. PMID: 27071739.

6) Wipf JE, Orlander JD, Anderson JJ. The effect of a teaching skills course on interns' and students' evaluations of their resident-teachers. Acad Med. 1999; 74(8): 938-42. PMID: 10495737.

7) Farrell SE, Pacella C, Egan D, Hogan V, Wang E, Bhatia K, et al. Resident-as-teacher: a suggested curriculum for emergency medicine. Acad Emerg Med. 2006; 13(6): 677-9. doi: 10.1197/j.aem.2005.12.014. PMID: 16569747.

8) Frattarelli LC, Kasuya R. Implementation and evaluation of a training program to improve resident teaching skills. Am J Obstet Gynecol. 2003; 189(3): 670-3. doi: 10.1067/s0002-9378(03)00879-2. PMID: 14526290.

9) Pushkin DB. Teacher training: A reference handbook: ABC-CLIO; 2001.

10) Wamsley MA, Julian KA, Wipf JE. A literature review of "resident-as-teacher" curricula: do teaching courses make a difference?. J Gen Intern Med. 2004; 19(5p2): 574-81. doi: 10.1111/j.15251497.2004.30116.x. PMID: 15109328, PMCID: PMC1492323.

11) Bernal Bello D, García de Tena J, Jaenes Barrios B, Martínez Lasheras B, de Arriba de la Fuente G, Rodríguez Zapata M. The resident as teacher: Medical students' perception in a Spanish university. Rev Clin Esp. 2014; 214(7): 371-6. PMID: 24889771.

12) Neher JO, Gordon KC, Meyer B, Stevens N. A five-step "microskills" model of clinical teaching. J Am Board Fam Pract. 1992; 5(4): 419-24. doi: 10.3122/jabfm.5.4.419. PMID: 1496899.

13) Ahn J, Jones D, Yarris LM, Fromme HB. A national needs assessment of emergency medicine resident-asteacher curricula. Intern Emerg Med. 2017; 12(1): 75-80. doi: 10.1007/s11739-016-1420-z. PMID: 27011214.

14) Katz-Sidlow RJ, Baer TG, Gershel JC. Providing rapid feedback to residents on their teaching skills: an educational strategy for contemporary trainees. Int $\mathrm{J}$ Med Educ. 2016; 7: 83-6. doi: 10.5116/ijme.56dc.908a. PMID: 26995390, PMCID: PMC4800021.

15) Isenberg-Grzeda E, Weiss A, Blackmore MA, Shen MJ, Abrams MS, Woesner ME. A Survey of American and Canadian Psychiatry Residents on Their Training, Teaching Practices, and Attitudes Toward Teaching. Acad Psychiatry. 2016; 40(5): 812-5. doi: 10.1007/s40596-016-0491-5. PMID: 26842486. 